\title{
A MICROSPORIDIAN PATHOGEN OF THE PREDATORY BEETLE RHIZOPHAGUS GRANDIS (COLEOPTERA: RHIZOPHAGIDAE)
}

\author{
Mustafa Yaman ${ }^{1}$, Renate Radek $^{2}$, Jaroslav Weiser ${ }^{3}$ and Çiçek Aydin ${ }^{1}$ \\ ${ }^{1}$ Department of Biology, Faculty of Arts and Sciences, Karadeniz Technical University, 61080, Trabzon, Turkey; \\ ${ }^{2}$ Institute of Biology/Zoology, Free University of Berlin, Königin-Luise-Str. 1-3, 14195 Berlin, Germany; \\ ${ }^{3}$ Department of Forest Protection and Game Management, Faculty of Forestry and Wood Sciences, Czech University of Life Sci- \\ ences, Kamýcká 1176, 16521 Praha 6 - Suchdol, Czech Republic
}

\begin{abstract}
A new Microsporidium sp. infects Rhizophagus grandis Gyllenhall, a beetle which preys on the bark beetle Dendroctonus micans Kugellan in Turkey. Mature spores are single, uninucleate, oval in shape $(3.75 \pm 0.27 \mu \mathrm{m}$ in length by $2.47 \pm 0.13 \mu \mathrm{m}$ in width), with a subapically fixed polar filament. The polar filament is anisofilar, coiled in 7-8 normal and 3-4 reduced coils. Other characteristic features of the microsporidium are the four/five nuclear divisions to form 16/32 (commonly 16) spores, subpersistent sporophorous vesicles (pansporoblasts) remaining till formation of the endospore, and the vesicles dissolved with free mature spores. The polaroplast is divided into three zones: an amorphous zone, dense layers, and a lamellartubular area extending to the central part of the spore.
\end{abstract}

The beetle Rhizophagus grandis Gyllenhall is an important predator of the bark beetle Dendroctonus micans in Turkey and is therefore reared and used in its biological control. Bark beetles are a serious pest of spruce in Europe and Asia (Weiser et al. 2003, Yaman 2008). In Europe, the damage caused by D. micans varies depending on region; the beetle plays an important role in destruction of pine forests in the Black Sea area and the Caucasus. It causes serious economic losses in Turkey, where it has been detrimental in an area of more than 250,000 ha. About 10 million spruce trees have been destroyed over the last 31 years in Turkey (see in Yüksel 1997). The predatory beetle $R$. grandis causes a significant decrease in the natural populations of pine beetles in Europe (Bevan and King 1983); no other potentially useful natural enemy of $D$. micans has been reported from Eurasia to date. This specific predator of pine beetles is considered to be a very effective bio-control agent, as it has a very high foraging proficiency and fecundity (Grégoire et al. 1985). In Turkey, the voracious attacks of $R$. grandis make them very efficient, which has led to the establishment of laboratories for their production and release. Since an infection of reared $R$. grandis by pathogens is an undesirable situation, we studied the health of the beetles in these laboratories. Recently, Yaman and Radek (2007) have recorded in these laboratories the alga Helicosporidium $\mathrm{sp}$., the first pathogen known to be common to $D$. micans and $R$. grandis. The present study adds another pathogen of $R$. grandis, a microsporidium that had not been previously encountered in this beetle or in any member of the Rhizophagidae.
Dead specimens of $R$. grandis originated from five predatory beetle-rearing laboratories in Artvin, Ordu and Trabzon (all in Turkey). To find infected individuals, beetles were dissected in Ringer's solution and wet smears were examined under a light microscope at magnifications of $\times 400-1000$. Microsporidian spores were measured, stained with Giemsa solution (after prefixation with methanol) and photographed using an Olympus BX51 microscope equipped with a DP-25 digital camera and DP2-BSW Soft Imaging System. The ultrastructure of the pathogen was studied by transmission electron microscopy (TEM) using previously reported techniques (Yaman and Radek 2005).

Microsporidian infections were found in adult $R$. grandis from two laboratories in Trabzon and Artvin. Fresh spores (Fig. 1) were oval, with only a minimum diversity in shape: $3.75 \pm 0.27(2.91-4.24) \mu \mathrm{m}$ long by $2.47 \pm 0.13(2.25-2.90) \mu \mathrm{m}$ wide $(\mathrm{n}=50)$. Giemsa-stained spores were $3.67 \pm 0.26$ (3.17-4.16) $\mu \mathrm{m}$ long by $2.40 \pm 0.21(2.0-2.79) \mu \mathrm{m}$ wide $(\mathrm{n}=50)$. Most Giemsa-stained spores (Fig. 2) had a dark metachromatic granule in the posterior pole, the stained remains of the Golgi apparatus. Vegetative stages were absent in the examined material. Scarce morula-like stages containing oval sporoblasts were non-persistent sporophorous vesicles (Fig. 1, sv).

The spores in TEM preparations have a more slender, long oval shape. The spore wall is 200 to $280 \mathrm{~nm}$ thick, consisting of an electron-dense, wavy exospore (60-80 nm) (Figs. 4, 5, 7; ex) and a thicker, electron-lucent, smooth endospore (200-210 nm; en). The fixation point of the polar filament is located subapically. At the fixation point, the endospore is attenuated, measuring only $80 \mathrm{~nm}$ in thickness (Figs. 4, 6; arrow). The spore content is enclosed by a plasmalemma (Fig. 6; pl). The anchoring disc (a) is a bulky bowl with a thickened, vacuolated border and is enclosed by a thin membrane. The polaroplast (Fig. 5, p2, p3; Fig. 6, p; Fig. 7, p1, p2,p3) is composed of three parts. The top layer (p1) is a confluent lobate mass, the central part (p2) is a series of 8-10 dense lamellae, and the posterior lamellar-tubular part (p3) consists of broader loops and layers protruding towards the central part of the spore. The polar filament is fixed with a bulb in its basal, manubrial part (Figs. 4, 7; fb) in the anchoring disc (a) and proceeds as a straight part (diameter 150-160 nm) to the posterior half of the spore, where it is coiled with a steep angle of tilt in 11/12 anisofilar coils (Figs. 4, 5). The first seven windings are perfectly formed, with 20-23 electron-lucent

Address for correspondence: M. Yaman, Department of Biology, Faculty of Arts and Sciences, Karadeniz Technical University, 61080, Trabzon, Turkey. Phone: +90 462 3772586; Fax: +90 462 3253195; E-mail: muyaman@hotmail.com 

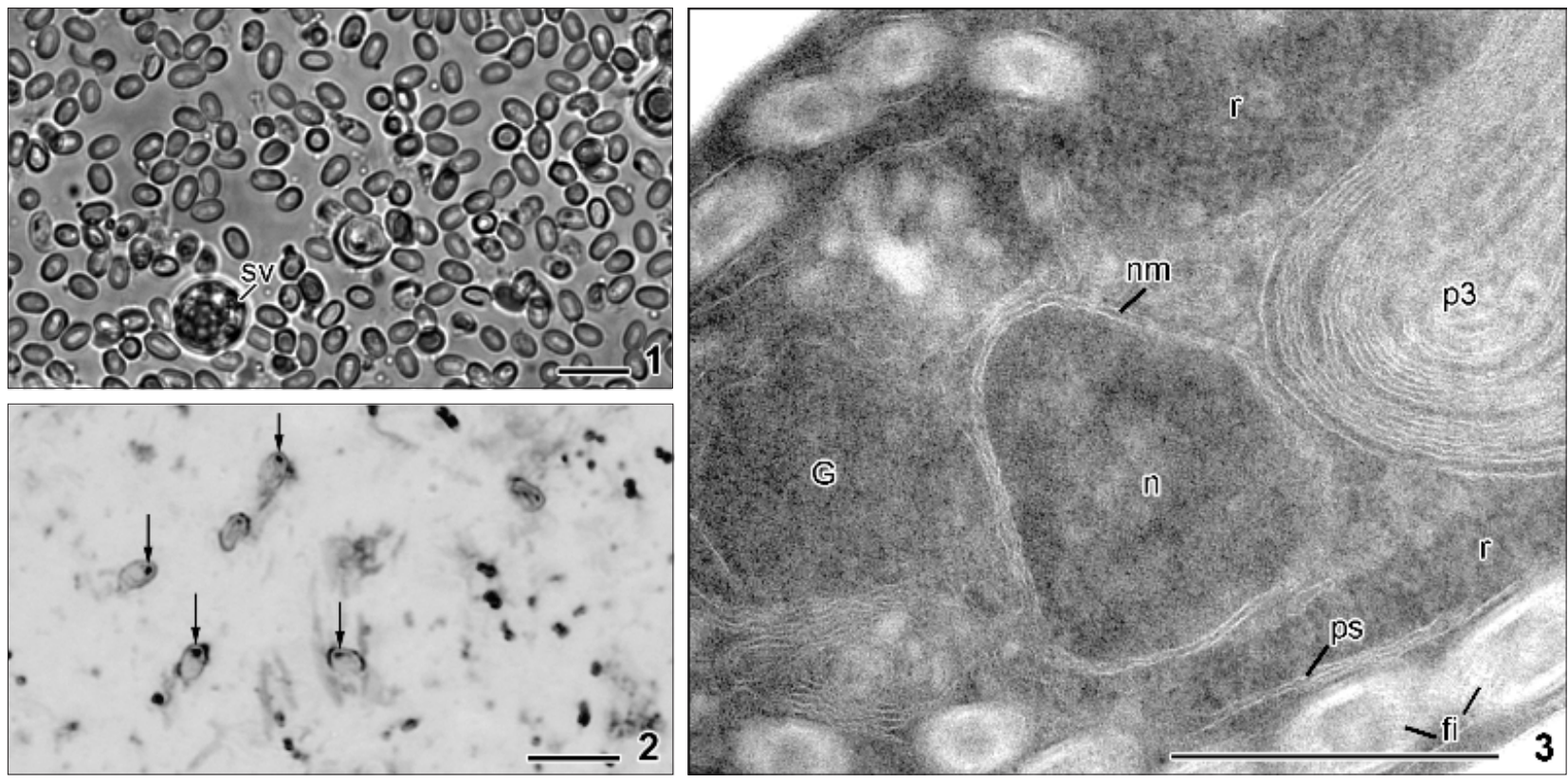

Figs. 1-3. Spores and stages of spore formation of Microsporidium sp. from Rhizophagus grandis in light (Figs. 1, 2) and transmission electron microscopy (TEM) (Fig. 3). Fig. 1. Water-mount of spores showing a minor variability in their size and shape. Free young spores and sporoblasts, sporophorous vesicle (sv). Fig. 2. Giemsa-stained smear with spores showing one dark, round, metachromatic granule (arrows). Fig. 3. Interior of mature spore with posterior part of polaroplast (p3), nucleus (n) bordered by two membranes $(\mathrm{nm})$ and Golgi apparatus $(\mathrm{G})$. In sections of the polar filament, electron-lucent fibrils (fi) are seen winding around the tube. The filament is enclosed in the polar sac (ps); ribosomes (r) fill the remaining space. Scale bars: Figs. 1, $2=10 \mu \mathrm{m}$; Fig. $3=1 \mu \mathrm{m}$.

cross-sections of fibrils which are included in the wall of the polar filament. This part of the filament is $150-160 \mathrm{~nm}$ in diameter. The last three or four windings are only $60-80 \mathrm{~nm}$ in diameter and do not show a ring of fibrils; only the amorphous surface layers of the polar tube are visible. In grazing sections of the polar filament, the electron-lucent fibrils are seen to be composed of a thread of spherical beads winding in loose turns (Fig.3; fi) along the filament. At the apical end the fibrils pass into a compact double-layer bulb (Figs. 4, 7; fb). In young spores, the polar filament is produced in vacuoles lined by the polar sac; later the polar sac remains attached to the coiled filament (Fig. 8; ps).

The spherical nucleus lies in the centre of the spore, slightly closer to the posterior end (Figs. 3-5; n). In the posterior area of the spore is the round mass of the Golgi apparatus $(\mathrm{G})$ which in Giemsa-stained smears can be seen as the metachromatic granule (Fig. 2; arrow) (Fig. 5; G). It is connected to regular lamellae enclosing the end of the polar filament.

Mature spores are interconnected by bridges of granular secretion (Fig. 5; sg). These are dried remains of a thin granulation filling the parasitophorous vacuole with spores.

Unfortunately, the study of only dead hosts limited our investigations in that only resistant parasite stages (spores and some of the sporoblasts) were well preserved; vegetative stages were not. Therefore, the merogonial part of the microsporidium life cycle could not be studied. Also, the infected tissues could not be exactly identified as they were already partially decayed at the time of study. However, the intact details of the internal structures of sporoblasts and mature spores demonstrated on ultrathin sections showed that these stages were viable. There is no evidence that all spores were produced in multisporal sporophorous vesicles (pansporoblasts), since many mature spores were found as single cells.
To date, there has been no record of a microsporidian infection in beetles of the genus Rhizophagus, and the only other known pathogen of $R$. grandis is the Helicosporidium sp. alga reported by Yaman and Radek (2007). The latter pathogen was found to also infect Dendroctonus micans, the specific prey of $R$. grandis (Yaman and Radek 2005, Yaman 2008). These authors suggested that infection of these two species of beetles may be mutual. The mode of transmission of Helicosporidium sp. differs in details from the transmission of microsporidia, and this is eventually why this new microsporidian pathogen has not been recorded from the local $D$. micans. There are, however, reports of pathogens from other Dendroctonus species (Table 1). Knell and Allen (1978) described the microsporidian Unikaryon minutum from Dendroctonus frontalis in the USA. This microsporidian was later included in the genus Canningia Weiser, Wegensteiner et Žižka, 1995. Weiser (1970) found three pathogens in Dendroctonus pseudotsugae in British Columbia, two microsporidia (Chytridiopsis typographi and Nosema dendroctoni) and one neogregarine (Ophryocystis dendroctoni).

The characteristic features of our microsporidium are four/ five nuclear divisions to form $16 / 32$ (commonly 16) spores, subpersistent sporophorous vesicles (pansporoblasts) remaining till formation of the endospore, and the vesicles dissolved with free mature spores. Additionally, the polaroplast consists of three parts; an amorphous part close to the apical end, a series of dense layers in the central part, and an area of tubular structures forming broad layers in the posterior part, deep in the centre of the spore. Oval, more or less persistent sporophorous vesicles with 16 oval spores are distinctive for the genus $D u$ boscqia Pérez, 1908 (Sprague et al. 1992, Larsson 1999). Duboscqia species produce rarely 8 , usually 16 uninucleate sporoblasts within an envelope. Similar stage was observed in our 

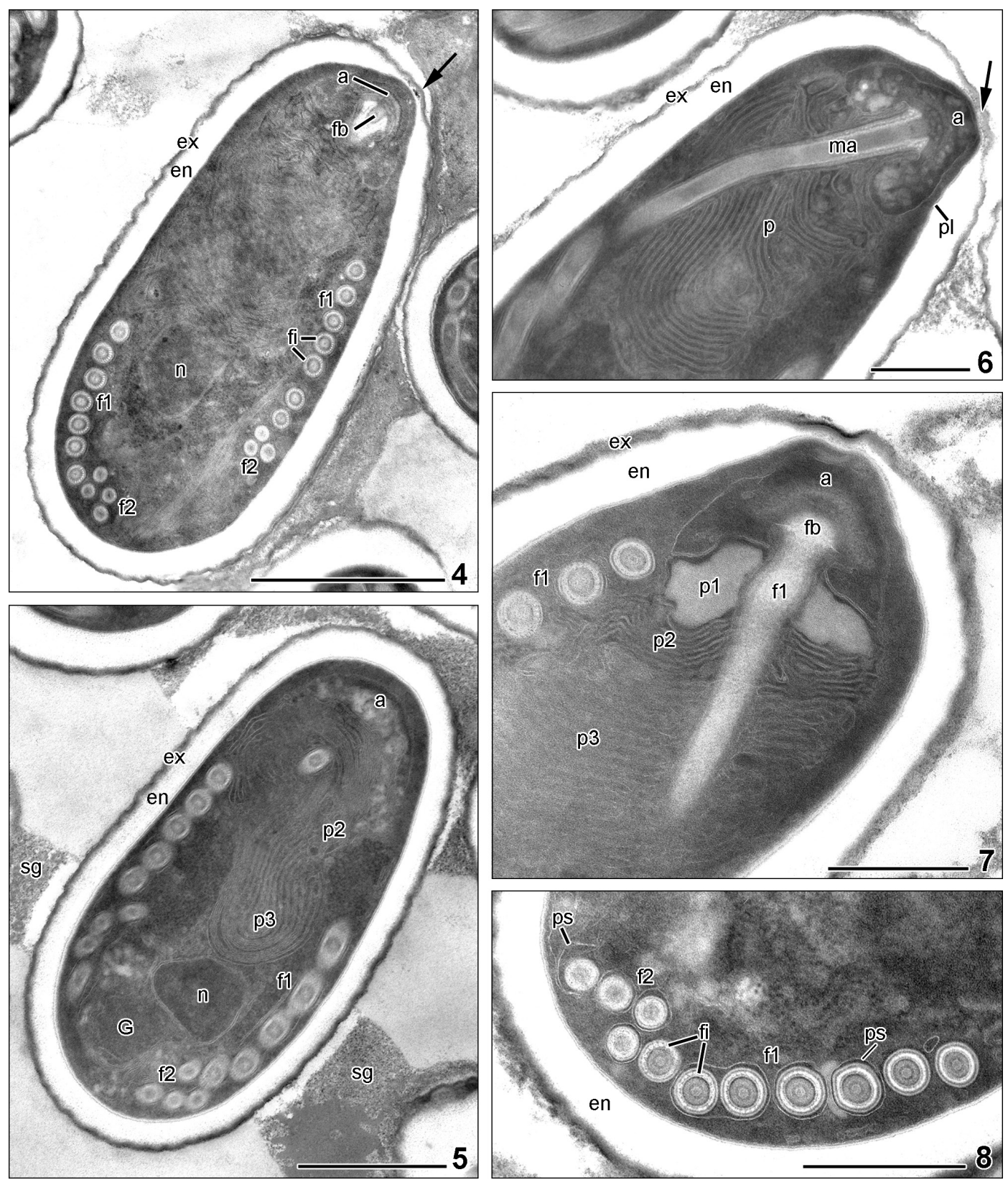

Figs. 4-8. Mature spores of Microsporidium sp. from Rhizophagus grandis in TEM. Fig. 4. Subapical fixation (arrow) of the polar filament. Anisofilar polar filament with 7 normal (f1) and 3-4 reduced (f2) coils. The normal polar tube (f1) contains 20-23 peripheral fibrils (fi). Nucleus (n) in posterior half of cell. Corrugated exospore (ex). The smooth electron-lucent endospore (en) is attenuated at the fixing point of the anchoring disc (a). The end bulb ( $\mathrm{fb}$ ) of the polar filament is fixed in the depression of the disc. Fig. 5. Five cross-sections of the thick (f1) and four cross-sections of the attenuated (f2) part of the polar filament. Posterior part of polaroplast (p3) extending to the centre of the spore. Single nucleus (n) and coil of Golgi membranes (G) in posterior part of the spore. Exospore (ex) and endospore (en) of constant thickness. Secretion granules and spherules (sg) form bridges between spores. Fig. 6. Apical part of spore with fixation of polar filament (arrow). Plasmalemma ( $\mathrm{pl}$ ) borders spore content. Manubrial part (ma) of the polar filament fixed in the depression of the anchoring disc (a). Polaroplast (p). Fig. 7. Apical part of spore with details of anchoring disc (a), fixation bulb (fb), and polaroplast with amorphous part (p1), dense lamellae (p2) and lamellar-tubular part (p3). Fig. 8. Posterior end of mature spore with cross-sections of the polar filament $(\mathrm{fl}, \mathrm{f2}$ ) with electron-lucent fibrils, enclosed in the persistent polar sac (ps). Scale bars: Figs. 4, $5=1 \mu \mathrm{m}$; Figs. $6-8=0.5 \mu \mathrm{m}$.

microsporidium. Unfortunately the ultrastructure of Duboscqia is unknown; therefore it is not possible to compare ultrastructural characters. The presporulation stages of Duboscqia are uninucleate and diplokaryotic, and the envelopment probably involves diplokaryotic cells (Becnel and Andreadis 1999). In contrast, we observed only uninucleate stages.

Comparison of the distinctive characteristics of our microsporidium with those of the species described in the current 
Table 1. Characteristics of the uninucleate microsporidian species from bark beetles or Rhizophagus grandis.

\begin{tabular}{|c|c|c|c|c|c|}
\hline Parasite & Host & Spore size $(\mu \mathrm{m})$ & $\begin{array}{l}\text { Spore } \\
\text { shape }\end{array}$ & $\begin{array}{l}\text { No. polar } \\
\text { filament coils }\end{array}$ & Reference \\
\hline Canningia minutum (Knell et Allen, 1978) & Dendroctonus frontalis & $2.2 \times 0.9$ & tubular & $6-7$ & Knell and Allen 1978 \\
\hline $\begin{array}{l}\text { Canningia spinidentis Weiser, Wegensteiner et Žižka, } \\
1998\end{array}$ & Pitiocteines spinidens & $1.9 \times 0.9$ & tubular & $5-6$ & Weiser et al. 1995 \\
\hline $\begin{array}{l}\text { Canningia tomici Kohlmayr, Weiser, Wegensteiner, } \\
\text { Händel et Zizka, } 2003\end{array}$ & Tomicus piniperda & $2.8 \times 1.4$ and $3.8 \times 2 *$ & oval & $5-6$ or $4-5$ & Kohlmayr et al. 2003 \\
\hline Microsporidium $\mathrm{sp}$ & Rhizophagus grandis & $3.8 \times 2.5$ & oval & $11-12$ & this paper \\
\hline Larssoniella duplicati Weiser, Holuša et Žižka, 2006 & Ips duplicatus & $3.5 \times 2$ and $2 \times 1.5^{*}$ & oval & $6-7$ or $5-6$ & Weiser et al. 2006 \\
\hline Unikaryon amitini Händel, 2001 & Ips amitinus & $1.8 \times 1$ & oval & $5-6$ & Händel 2001 \\
\hline $\begin{array}{l}\text { Unikaryon montanum Weiser, Wegensteiner et Žižka, } \\
1998\end{array}$ & Ips typographus & $2 \times 1$ and $1.5 \times 1^{*}$ & oval & $7-8$ or $5-6$ & Weiser et al. 1998 \\
\hline $\begin{array}{l}\text { Unikaryon polygraphi Weiser, Händel, Wegensteiner } \\
\text { et Žižka, } 2002\end{array}$ & $\begin{array}{l}\text { Polygraphus poli- } \\
\text { graphus }\end{array}$ & $2.8 \times 1$ and $2.2 \times 1 *$ & oval & $6-7$ or $5-6$ & Weiser et al. 2002 \\
\hline
\end{tabular}

*Spores occur in two sizes.

genera shows that our microsporidium is different. We consider our organism, tentatively classified in the collective group $\mathrm{Mi}$ crosporidium, to be a distinct, undescribed species that might even deserve erection of a new genus. Further studies, however, are needed to finally resolve the taxonomic status of the new microsporidian.

The study was financially supported by the Scientific and Technological Research Council of Turkey (research project 107T166) and, in part, by the Ministry of Agriculture of the Czech Republic (grant No. 7136). The authors wish to express their thanks to Prof. Dr. Klaus Hausmann, Berlin, for making this study possible, and to Frederic Bartlett for linguistic comments.

\section{References}

Becnel J.J., Andreadis T.G. 1999: Microsporidia in Insects. In: M. Wittner (Ed.), The Microsporidia and Microsporidiosis. American Society for Microbiology, Washington, DC, pp. 447-501.

Bevan D., King C.J. 1983: Dendroctonus micans Kug., a new pest of spruce in U.K. Commonwealth For. Rev. 62: 41-51.

Grégoire J.C., Merlin J.J., Pasteels M., Jaffuel R., Vouland G., Schvester D. 1985: Biocontrol of Dendroctonus micans by Rhizophagus grandis Gyll. (Col., Rhizophagidae) in Massif Central (France). Z. Angew. Entomol. 99: 182-190.

HÄNDEL U. 2001: Untersuchungen zum Gegenspielerkomplex assoziirt lebender Fichtenborkenkäfer (Col.: Scolytidae) aus naturnahen und sekundären Fichtenbeständen unter besonderer Berücksichtigung der Pathogene. PhD Dissertation, BOKUUniversity, Wien, 185 pp.

Knell J.D., Allen G.E. 1978: Morphology and ultrastructure of Unikaryon minutum sp. n. (Microsporida, Protozoa), a parasite of the southern pine beetle Dendroctonus frontalis. Acta Protozool. 17: 271-278.

Kohlmayr B., Weiser J., Wegensteiner R., Händel U., Zizka Z. 2003: Infection of Tomicus piniperda (Col., Scolytidae) with Canningia tomici sp. n. (Microsporidia, Unikaryonidae). J. Pest Science 76: 65-73.

LARSSON J.I.R. 1999: Identification of microsporidia. Acta ProtoZool. 38: 161-197.

Sprague V., Becnel J.J., Hazard E.I. 1992: Taxonomy of Phylum Microspora. Crit. Rev. Microbiol. 18: 285-395.
Weiser J. 1970: Three new pathogens of the douglas fir beetle, Dendroctonus pseudotsugae: Nosema dendroctoni n. sp, Ophryocystis dendroctoni n. sp. and Chytridiopsis typographi n. comb. J. Invertebr. Pathol. 16: 436-441.

Weiser J., Händel U., Wegensteiner R., ŽıžKa Z. 2002: Unikaryon polygraphi sp. n. (Protista: Microspora): a new pathogen of the four-eyed spruce bark beetle Polygraphus poligraphus (Col., Scolytidae). J. Appl. Entomol. 126: 148-154.

Weiser J., Holuša J., ŽıžKa Z. 2006: Larssoniella duplicati n.sp. (Microsporidia, Unikaryonidae), a newly described pathogen infecting the double-spined spruce bark beetle, Ips duplicatus (Coleoptera, Scolytidae) in the Czech Republic. J. Pest Sci. 79: 127-135.

Weiser J., Wegensteiner R., Händel U., ŽıžKa Z. 2003: Infections with the ascomycete fungus Metschnikowia typographi sp. nov. in the bark beetles Ips typographus and Ips amitinus (Coleoptera, Scolytidae). Folia Microbiol. 48: 611-618.

Weiser J. Wegensteiner R., ŽIŽKa Z. 1995: Canningia spinidentis gen. et sp. n. (Protista: Microspora), a new pathogen of the fir bark beetle Pitiocteines spinidens. Folia Parasitol. 42: 1-10.

Weiser J. Wegensteiner R., ŽIŽKa Z. 1998: Unikaryon montanum sp. n. (Protista: Microspora) a new pathogen of the spruce bark beetle, Ips typographus (Coleoptera: Scolytidae). Folia Parasitol. 45: 191-195.

YAMAN M. 2008: Distribution and occurrence of the insect pathogenic alga Helicosporidium sp. (Chlorophyta: Trebouxiophyceae) in the populations of the great spruce bark beetle, Dendroctonus micans (Kugelann) (Coleoptera: Curculionidae, Scolytinae). North-West. J. Zool. 4: 99-107.

YAMAN M., RADEK R. 2005: Helicosporidium infection of the great European spruce bark beetle, Dendroctonus micans (Coleoptera: Scolytidae). Eur. J. Protistol. 41: 203-207.

YAMAN M., RADEK R. 2007: Infection of the predator beetle Rhizophagus grandis Gyll. (Coleoptera, Rhizophagidae) with the insect pathogenic alga Helicosporidium sp. (Chlorophyta: Trebouxiophyceae). Biol. Control 41: 384-388.

YüKSEL B. 1997: The infestations of Dendroctonus micans (Kug.) and role of Rhizophagus grandis (Gyll.) about establishment of biological equilibrium. III. Ulusal Ekoloji ve Çevre Kongresi Program1, Biyologlar Derneği, Bildiriler Kitabı, 3-5 Eylül 1997, Kırşehir, pp. 375-385. (In Turkish.)

Received 9 March 2009

Accepted 20 January 2010 